\title{
Zakat Management in Indonesia: Legal Political Perspective
}

\author{
Imam Yahya \\ Universitas Islam Negeri Walisongo Semarang - Indonesia \\ e-mail:_imamyahya@yahoo.co.id
}

\begin{abstract}
This article aims to describe the management of zakat in Indonesia in a political and legal perspective carried out by BAZNAS (Badan Amil Zakat Infaq and Sadaqah) and LAZ (Lembaga Amil Zakat). Management of zakat management in a political-law approach is manifested in the zakatmanagement regulations in Indonesia, namely Law no. 23 of 2011 concerning Zakat Management. Through literature research with a political-law approach, this research finds the following three points. First, the existence of BAZNAS is legitimized by law as a non-structural institution under the President, which has the authority to manage zakat, whether it is the collection, distribution or development of zakat assets. Second, as a consequence, taxes that have been paid through central BAZNAS or regional BAZNAS can reduce taxable assets. Third, BAZNAS has the power to recommend LAZ as well as supervise LAZ's performance at all levels, and the results are reported to BAZNAS.
\end{abstract}

Keywords: zakat management; politics of law; BAZNAS; LAZ

\section{प}

Artikel ini bertujuan untuk mendeskripsikan pengelolaan zakat di Indonesia dalam perespektif politik hukum yang dilakukan BAZNAS (Badan Amil Zakat Infaq dan Sadaqah) dan LAZ (Lembaga Amil Zakat). Manajemen pengelolaan zakat dalam pendekatan politik hukum terwujud dalam regulasi manajemen zakat di Indonesia yang terdapat dalam Undang-Undang Pengelolaan Zakat No. 23 tahun 2011. Melalui penelitian kepustakaan dengan pendekatan politik hukum, penelitian ini menemukan tiga hal berikut.Pertama, keberadaan BAZNAS dilegitimasi oleh undang-undang sebagai lembaga non struktural di bawah Presiden yang memiliki otoritas dalam mengelola zakat, baik pengumpulan, pendistribusian ataupun pengembangan harta zakat. Kedua, konsekwensinya, pajak yang sudah dibayarkan lewat BAZNAS pusat atau BAZNAS daerah bisa mengurangi harta kena pajak. Ketiga, BAZNAS mempunyai kekuasaan untuk merekomendasikan LAZ sekaligus mengawasi kinerja LAZ di semua jenjang dan hasilnya dilaporkan kepada BAZNAS.

Kata Kunci: manajemen zakat; politik hukum; BAZNAS; LAZ 
Imam Yahya

\section{Introduction}

Law No. 23 of 2011 regarding Zakat Management emphasizes the duties of zakat managers ('ämil), namely collecting, distributing and utilizing zakat. This institution is BAZNAS (Badan Amil Zakat Nasional) as a non-structural state institution that is responsible to the President through the Indonesian Minister of Religion. ${ }^{1}$ The law aims to regulate the interests of the people more carefully and comprehensively. This is because zakat is a form of māliyah ijtimā'izyah (people's property) which has great potential in supporting the fundamentals of public finance. ${ }^{2}$ This objective shows that the arrangement of zakat as the strength of the Muslims for the benefit of society finds its urgency. This condition is not only in Indonesia but also in several Islamic countries in the world. ${ }^{3}$

Zakat is a familiar term in Indonesia, especially for Muslims. Almost all of them understand that zakat is the percentage of assets that must be spent by Muslims. Apart from its implementation as an obligation (mahdah). It also has social value. It is given to people who are entitled to receive it (mustahiq) as many as eight groups, namely poor, poor, amil, converts, slave, ghārim, sabīlillāh and ibn sabil..$^{4}$

\footnotetext{
1 Widyawati, 'Filantropi Islam dan Kebijakan Negara Pasca Orde Baru: Studi tentang UU Zakat dan UU Wakaf' (UIN Syarif Hidayatullah, 2011), 55-60; Saidurrahman, "The Politics of Zakat Management In Indonesia: The Tension Between BAZ and LAZ, Journal of Indonesian Islam 7, no. 2 (2013): 375.

2 Arskal Salim, The Shift in Zakat Practice in Indonesia: From Piety to an Islamic Socio-PoliticalEconomic System (Chiang Mai:Silkworm Books, 2008), 62; Elly Triantini Zusiana, 'Integrasi Hukum Pajak dan Zakat di Indonesia: Telaah Terhadap Pemikiran Masdar Farid Mas'udi', Al-Ahkam: Jurnal Pemikiran Hukum Islam 23, no. 2 (2013): 185; Ilyas Supena and Darmuin, Manajemen Zakat (Semarang: Walisongo Press, 2009), 21.

3 Dian Masyita, 'Lessons Learned of Zakah Management from Different Era and Countries', AlIqtishad: Jurnal Ilmu Ekonomi Syariah (Journal of Islamic Economics) 10, no. 2 (2018): 446-48; Ahmed Esawe, Karimt Esawe, and Narges Esawe, 'Using Zakat to Build the Resilience of Communities to Disasters: Evidence from Egypt', SSRN Electronic Journal, 2019, 7-9, https://doi.org/ 10.2139/ssrn.3331506; Tsalis Syaifuddin, 'Implementation of Data Envelopment Analysis (DEA) in Measuring the Efficiency Zakat Fund Management', Indonesian Journal of Islamic Economics Research, 2019, 54-56, https://doi.org/10.18326/ijier.v1i1.2872; Syarul Azman Shaharuddin et al., The Relationship between Impact of Zakat Distribution and Religious Practice among Muallaf in Selangor', Humanities and Social Sciences Reviews, 2019, 372-75, https://doi.org/10.18510/hssr.2019.7448.

${ }^{4}$ Oyong Lisa, 'Implementation of Management Zakat as a Local Revenue', Journal of Asian Scientific Research 5, no. 8 (2015): 418-19, https://doi.org/10.18488/journal.2/2015.5.8/2.8.418.430; Monzer Kahf, 'Zakat: Unresolved Issues in the Contemporary Fiqh', Journal of Islamic Economics, 1989, 3-6; Elly Triantini Zusiana, 'Integrasi Hukum Pajak dan Zakat di Indonesia: Telaah Terhadap Pemikiran Masdar Farid Mas'udi'; Putu Widhi Iswari and Maskur Rosyid, 'Tinjauan Prinsip Good Governance dan
} 
For Muslims, who constitute the majority in Indonesia $(87.2 \%$ of all citizens), zakat is a huge potential. It is not an exaggeration if BAZNAS together with the Islamic Development Bank (IDB) have expectations about the potential for zakat in Indonesia as much as Rp. 233 trillion. ${ }^{5}$ This is a lot of numbers for fundraising that prioritizes religiosity values.

This enormous potential can be a strength of religiosity as well as a basis for economic strength that can affect the condition of the Indonesian people. Therefore, if it is not managed properly, interests that are counterproductive with the aim of zakat will easily enter. The purpose of zakat is to dynamize property so that all people can enjoy it.

Zakat, in the context of the Indonesian state, is not only a matter for individual Muslims but also a public affair. This is because zakat matters involve many parties. The state, in this case, is present by providing zakat regulations governing the management, institutions, and sustainability of zakat in Indonesia. ${ }^{6}$

The institutionalization of zakat through BAZNAS, from the perspective of political law, is a logical consequence of a country that has a pattern of facultative relationships between religion and politics. Allan Samson, in his political language, states that this pattern is categorized as a trichotomy perspective. ${ }^{7}$ The state does not regulate the law of implementing zakat but regulates the operation of zakat in society.

The presence of the Zakat Management Law places BAZNAS as an institution that has strong supremacy. BAZNAS as a zakat regulator as well as an actor in the collection, distribution and development of zakat assets assisted by

Perpektif Islam dalam Operasional Lembaga ZIS', Jurnal Manajemen Zakat dan Wakaf1, no. 1 (12 April 2020): 90-91, http://ejournal.iainsurakarta.ac.id/index.php/filantropi/article/view/2367.

5 Clarashinta Canggih, 'Potensi dan Realisasi Dana Zakat Indonesia', Al-Uqud: Journal of Islamic Economics 1 (2017): 2548-3544.

${ }^{6}$ Hamsah Hasan, 'Hubungan Islam dan Negara: Merespons Wacana Politik Islam Kontemporer di Indonesia', Al-Ahkam, 2015, https://doi.org/10.21580/ahkam.2015.1.25.192; Elly Triantini Zusiana, 'Integrasi Hukum Pajak dan Zakat di Indonesia: Telaah Terhadap Pemikiran Masdar Farid Mas'udi'; Iswari and Rosyid, 'Tinjauan Prinsip Good Governance dan Perpektif Islam dalam Operasional Lembaga ZIS', 95-98.

7 Abdul Ghofur, 'Pergulatan Hukum dan Politik dalam Legislasi UU No. 21 Tahun 2008 tentang Perbankan Syari'ah', Al-Ahkam, 2013, https://doi.org/10.21580/ahkam.2013.23.1.73; Bahtiar Effendy, Islam Dan Negara: Transformasi Pemikiran dan Praktek Politik Islam di Indonesia Uakarta: Paramadina, 1998), 32. 
LAZ (Lembaga Amil Zakat). ${ }^{8}$ National LAZ and regional LAZ must obtain a recommendation from the central and regional religious ministries according to their level. Therefore, he must follow the required administrative rules strictly.

This is the condition of zakat management in Indonesia, which gives great authority to BAZNAS, both as a regulator and operator of zakat. He acts as a monitor for zakat institutions in carrying out their duties in society. LAZ must report its duties as amil zakat to BAZNAS at all levels. Apart from that, BAZNAS also acts as a zakat operator that competes with other zakat institutions. The granting of this role is closely related to government policy in regulating zakat management in Indonesia which is manifested in the Zakat Management Law. As a regulation, the law is a state law politics in regulating the pattern of social generosity of Muslims. This great potential requires careful monitoring so that it can run well.

Through literature studies, data related to zakat governance in Indonesia were collected. Once collected, the data is analyzed using a political science approach to law. Thus, this research is qualitative in nature and is presented with a descriptive-analytic method.

\section{Politics of law}

According to Andrew Heywood, politics means power in the form of the ability of a person or group to influence other people or groups to comply with their wishes. ${ }^{9}$ This can also be interpreted as an activity of a nation which aims to create, maintain and amend general regulations governing life. This definition implies that political society, on the one hand, becomes an arena for collaboration. Still, on the other hand, it can trigger conflict, both between individuals, individuals and groups, as well as conflicts between groups in society.

Politics can also be defined as the art and science of gaining power, both constitutionally and non-constitutionally. So, talking politics is the same as talking about rules relating to citizens and government to achieve prosperity. Al-

\footnotetext{
8 Saidurrahman, "The Politics of Zakat Management In Indonesia: The Tension Between BAZ and LAZ',373.

9 Andrew Heywood, Political Theory An Introduction (New York: PALGRAVE MACMILLAN Houndmills, 2004), 48.
} 
Mawardī stated that politics is away so that he needs a leader (al-khaliffah).10 Leadership is an obligation, so being active in politics is also the obligation of Muslims. Effendi stated that politics and the state must complement each other. Islam and the state are seen as community entities that complement each other in realizing common ideals. ${ }^{11}$

Mahfud MD defines realities like this as Recht Politik (legal politics), namely the process of forming positive laws that cannot be separated from the surrounding political influence. ${ }^{12}$ Political law, as the direction of state policy, is in the form of general principles that function to regulate or resolve public affairs, including matters relating to the livelihoods of many people such as zakat management concerning economic and welfare issues.

The management of zakat funds for Muslims in positive law in Indonesia is regulated in Law no. 38 of 1999 concerning Zakat Management which was later renewed by Law No. 23 of 2011 concerning Zakat Management. Through this law, the state is present to regulate zakat administratively. The Zakat Law is based on Article 32 of the 1945 Constitution, which regulates citizen security in carrying out worship by their respective religions and beliefs. The existence of this law is a state rule that helps the running of the Muslim zakat worship.

The issuance of the Zakat Management Law is a success of Islamic law in legal politics in Indonesia. Since the New Order era until now, the journey of Islamic law in Indonesia has always had a place in the development of national law. Islamic law is not only an authoritative source of national law but also a persuasive source of national law. ${ }^{13}$

As an authoritative source, Law no. 16 of 2019 concerning Amendments to Law No.1 of 1974 concerning Marriage, Law no. 7 of 1989 concerning Religious Courts, Law no. 3 of 2006 concerning Amendments to Law no. 7 of 1989, Law no. 50 of 2009 the Second Amendment to Law no. 7 of 1989, Law no. 38 of 1999

\footnotetext{
${ }^{10}$ Abū al-Hasan Al-Mawardī, Al-Ahkām Al-Sulțāniyah (Beirut: Dār al-Fikr, n.d.), 5.

${ }^{11}$ Effendy, Islam dan Negara: Transformasi Pemikiran dan Praktek Politik Islam di Indonesia, 12-13; Hasan, 'Hubungan Islam dan Negara: Merespons Wacana Politik Islam Kontemporer di Indonesia', 3538.

12 Moh Mahfud MD, Politik Hukum di Indonesia (Jakarta: LP3ES, 1998), 24-25.

${ }_{13}$ Ismail Suny, 'Tradisi dan Inovasi Keislaman di Indonesia dalam Bidang Hukum Islam', in Hukum Islam dalam Tatanan Masyarakat Indonesia, ed. Cik Hasan Bisri (Jakarta: Logos Publishing House, 1998), 96.
} 
concerning Zakat Management, Law no. 23 of 2011 concerning Changes in Management of Zakat, Law no. 41 of 2004 concerning Waqf, Law no. 7 of 1992 concerning Banking. Meanwhile, as a persuasive source, the values of Islamic law provide the basis for drafting legislation in Indonesia. Among them is the application of the death penalty as one of the official laws in Indonesia.

The advantages of Islamic law cannot be separated from the pattern of Islamic and political relations in Indonesia, which has been mutually beneficial. Indonesia is not a religious state but also not a secular country. In certain matters, religion is present in religious matters, for example, regarding the realization of the pilgrimage. In this case, the state regulates the technical implementation of the pilgrimage for the congregation, starting from the homeland to the destination of worship.

There are three patterns of relationship that are recognized in the context of religion and state. ${ }^{14}$ First, integrality relationship pattern. This pattern states that religion and state are an inseparable unity. Therefore, the two institutions must unite, and it is stated that the state is part of religion. Second, the pattern of secularistic relations. This second pattern places religion and state as two different forms of identity, and each has their respective fields of work. So that between religious regulations and state matters are separated.

Third, the symbiotic relationship pattern. This third paradigm states that between religion and state are two different identities, but the two entities complement and need each other. Through the symbiotic relationship paradigm, the state is present in the implementation of zakat, but only on technical, administrative issues. Meanwhile, substantially, the teachings of zakat as part of religious law are not discussed in the Zakat Law.

\section{Zakat in the Political View of Law in Indonesia}

Issuance of Law no. 23 of 2011 concerning Zakat Management provides an understanding that zakat has full political support from the government.15 More than that, zakat is also used as a deduction for taxable assets in a company. This

14 Hasan, 'Hubungan Islam dan Negara: Merespons Wacana Politik Islam Kontemporer di Indonesia', 34-38; Jaih Mubarok, Fiqh Siyasah (Bandung: Pustaka Bani Quraisy, 2005), 57.

15 Abdullah Junaidi, 'Institusi Pengelola Zakat dalam Hukum Positif di Indonesia', ZISWAF 5, no. 1 (2018): 171-85; Saidurrahman, "The Politics of Zakat Management In Indonesia: The Tension Between BAZ and LAZ', 377. 
means that the existence of zakat is taken into account in the tax accounting system in Indonesia.

The process of institutionalizing BAZNAS into a state institution is aimed at strengthening its position as an institution that organizes social fundraising (philanthropy) based on the following reasons. First, BAZNAS is a national Islamic philanthropic organization. Second, building public trust that no one will misuse zakat assets because the state controls BAZNAS performance. Third, the management of BAZNAS consists of government, community, and professional elements. The hope is that zakat assets can be used according to the context of the era. ${ }^{16}$

Zakat regulation through the Zakat Management Law is based on the direction of legal policies applied in Indonesian legislation. This is referred to by Mahfud MD as the legal policy or official policy line on the law (legal politics) that is applied in Indonesia. This policy is an implementation of the ideals of the state, namely the welfare of society. According to him, there are 3 criteria in analyzing a country's legal politics; first, state policy in enforcing the law as an implementation of the ideals of the state. Second, the background of the emergence of legal policies applied in a country. Third, the aspect of law enforcement that is implemented. ${ }^{17}$

However, the efforts to advance BAZNAS cannot be felt directly by the community. He has to do a lot of work to realize his main goal as the sole institution that administers zakat management in this country. Several government policies formulated in the Zakat Management Law, provide an overview of the political law applied by the Indonesian government as follows.

\section{1) BAZNAS as a Non-Structural Government Institution}

The determination of BAZNAS as a non-structural institution (LNS) was caused by the government's desire to control the implementation of its work

\footnotetext{
16 Caturida Meiwanto Doktoralina, 'Mobilisation of Income Zakat Payment In Indonesia', IKONOMIKA: Jurnal Ekonomi Dan Bisnis Islam 3, no. 2 (2018): 191-96; Yahya Imam, Institusionalisasi Zakat Pasca UU Nomor 23.2011: Kontestasi Lembaga Zakat BAZNAS dan LAZ Kota Semarang (Semarang: LP2M UIN Walisongo, 2015); Syaifuddin, 'Implementation of Data Envelopment Analysis (DEA) in Measuring the Efficiency Zakat Fund Management', 55.

17 Moh Mahfud MD, Membangun Politik Hukum, Menegakkan Konstitus (Jakarta: LP3ES, 2006), 5; Anna Triningsih, 'Politik Hukum Pengujian Peraturan Perundang-Undangan dalam Penyelenggaraan Negara', Jurnal Konstitusi 13, no. 1 (20 May 2016): 126-27, https://doi.org/10.31078/jk1316.
} 
by the private sector and civil society. The state facilitates citizens in practising some of their religious teachings and beliefs. Through independent laws, zakat management can be regulated according to the needs of the community. Meanwhile, the issue of the substance of zakat remains the authority of the Muslim faith. In this case, the state is not allowed to interfere in substantive matters. The timing of zakat implementation and zakat allocation is not the authority of BAZNAS.

As 'ämil zakat, BAZNAS is one of the zakat așnaf. The existence of 'ámil is essential because zakat can be collected as a whole and distributed appropriately. Through 'âmil zakat, rich people will be moved to pay zakat. As for mustahiq, zakat is distributed appropriately. BAZNAS research results in 2018 show that the Indonesian Muslim community has not paid zakat maximally. Of course, it is not only the fault of the people but also Muslim thinkers and figures in this country. Until now, no zakat institution has become an icon of zakat in Indonesia. The contestation between zakat institutions that advertise in various media has confused the public. This is because zakat is not only a transfer of zakat to 'âmil but is an implementation of individual obedience to God. ${ }^{18}$

The paternalistic Indonesian society is easier to empower than other Muslim societies. Statements of charismatic figures, for example, will be a reference in paying zakat. The problem of zakat will be a problem of sustainability that is not easily resolved throughout the ages. ${ }^{19}$ This is because zakat is a form of individual theological worship with a social dimension.

Besides, public awareness of paying zakat only focuses on zakat fitrah. Meanwhile, zakat māl has not received a balanced portion..$^{20}$ Understanding that is not comprehensive enough is alleged to be the main cause. Zakat as an economical solution is thus only considered a momentary potential, especially in the month of Ramadan. There are at least three reasons why the

\footnotetext{
18 Syaifuddin, 'Implementation of Data Envelopment Analysis (DEA) in Measuring the Efficiency Zakat Fund Management', 51-52.

${ }^{19}$ Monzer Kahf, 'Zakat: Unresolved Issues in the Contemporary Fiqh', 15-21.

${ }^{20}$ Canggih,'Potensi dan Realisasi Dana Zakat Indonesia', 22.
} 
zakat potential is not maximal. ${ }^{21}$ First, the lack of public understanding of the teachings of zakat. Second, the lack of socialization to muzakkīs so that they consider only zakat fitrah to be issued. Third; Âmil zakat, from the village level to the district/city level, is still partial.

Direct management of zakat (muzakki to mustahiq) is still widely found. As the cause is the growth of zakat collection institutions, the low level of public trust in 'āmil zakat, and 'âmil zakat is still considered a side profession. Sudden 'āmil zakat scattered in several social organizations, socio-religious organizations, or places of worship, often shows unpreparedness in managing zakat, donations and alms. ${ }^{22}$ Although the 'āmil institution model does not violate shara', the effectiveness and benefit of zakat cannot run optimally. It is inversely proportional to the potential for zakat as previously explained. There are several principles for people to believe in 'āmil, namely 1) accountability; can account for zakat funds. 2) transparent; the existence of professional financial reports. 3) institutional reputation of zakat; 4) performance; the emergence of zakat institutions. ${ }^{23}$

Zakat is not only about restrictive religious rituals, but it also becomes a political problem with a transcendent dimension. As ritual worship, zakat has provisions on the clarity of the origin and purpose of zakat to be collected and distributed to those who have the right. Textually, zakat is collected from the aghniyā' (rich people) to be given to mustahiq (people who are entitled). Meanwhile, as social worship, zakat is not only given consumptively to the mustahiq but is also given productively as an effort to increase the economic status of the poor. In fact, this productive zakat has become the mainstay of zakat institutions which have gained a lot of trust from the public.

${ }^{21}$ Irfan Syauqi Beik, 'Fiqh Of Asnaf In The Distribution Of Zakat: Case Study Of The National Board Of Zakat Of Indonesia (Baznas)', AL-INFAQ: Jurnal Ekonomi Islam 6 (2015): 201-16; Shaharuddin et al., 'The Relationship between Impact of Zakat Distribution and Religious Practice among Muallaf in Selangor'; Doktoralina, 'Mobilization of Income Zakat Payment In Indonesia', 371-75.

22 Beik, 'Fiqh Of Asnaf In The Distribution Of Zakat: Case Study Of The National Board Of Zakat Of Indonesia (Baznas)'; Shaharuddin et al., 'The Relationship between Impact of Zakat Distribution and Religious Practice among Muallaf in Selangor'; Doktoralina, 'Mobilization of Income Zakat Payment In Indonesia', 371-75.

${ }^{23}$ Hasan Mukhibad, Fachrurrozie Fachrurrozie, and Ahmad Nurkhin, 'Determinant of the Intention of Muzakki to Pay Professional Zakat', Share: Jurnal Ekonomi dan Keuangan Islam, 2019, 57-60, https://doi.org/10.22373/share.v8i1.4573; Syaifuddin, 'Implementation of Data Envelopment Analysis (DEA) in Measuring the Efficiency Zakat Fund Management', 51. 
The existence of BAZNAS is a hope that zakat management will be more professional. Through the Zakat Management Law, BAZNAS performance is monitored by the government and is responsible to the President. This is as stated in Article 5, Paragraph (1), (2), and (3). ${ }^{24}$ As an LNS regulated through law, BAZNAS has a strong bargaining position. It will continue to exist as long as its function as an institution for collecting, distributing and developing zakat in Indonesia is carried out. Meanwhile, in terms of operationalization of the institution, BASNAS receives an annual fee from the government, both central and regional.

The appointment of BAZNAS as an LNS (non-structural institution) is the government's effort to monitor Islamic philanthropy in society. The pattern of relations between Islam and the state is an option, so that zakat, which is the power of Muslims, can be monitored by the government.25 Although in technical terms of operation, BAZNAS's work is fully regulated by BAZNAS regulations.

BAZNAS, with its status as LNS, on the other hand, can be a barrier to innovation and dynamism. This is due to the following reasons. First, BAZNAS is considered to be the government's long arm in taking community social funds. Even though it is known that social funds are voluntary, he cannot be expelled on coercion, including from BAZNAS. Second, in a democratic country, the entry of government hands weakens public trust.

\section{2) Zakat as a deduction for taxable assets}

As a country with the largest Muslim population in the world, Indonesia does not necessarily accommodate zakat regulations into black and white regulations like zakat fiqh. The zakat law provides a guideline on the implementation of zakat in Indonesia so that zakat worship which is the obligation of Muslims, can be carried out properly.

Substantively, the Zakat Management Law deals with the social aspects of zakat, namely the method of collecting and distributing zakat to the mustahiq. Many studies have indicated that zakat has great potential for poverty alleviation in Indonesia. However, the reality in society is that zakat

\footnotetext{
${ }^{24}$ Canggih, 'Potensi Dan Realisasi Dana Zakat Indonesia', 22-23.

25 Moh Dahlan, 'Hubungan Agama dan Negara di Indonesia, ANALISIS:Volume 14, Nomor 1, Juni 2014.', ANALISIS: Jurnal Studi Keislaman 1 (2014): 12-13.
} 
has not become a major force that can transform from a poor to a rich society-especially when compared to the taxes imposed in Indonesia. Taxes are a state obligation for all citizens, while zakat is more due to high religious awareness.

There are two opinions about the position of zakat and tax in reality in society. First, for those who have already taxed, they are not obliged to give zakat. This is based on the function of both of them for the benefit of the ummah. Second, zakat and tax have different legal contexts. If the state levies the tax, and the offender will get a sanction from the state, then zakat is withdrawn by āmil, and the offender is submitted to his belief in God Almighty. ${ }^{26}$

The two opinions above have coloured the dynamics of zakat thought in Indonesia. Viewed from the positive side, discussions about the relationship between zakat and taxes will certainly increase the enthusiasm for paying zakat among Muslims. Referring to the history of zakat in the first century Hijriyah, zakat and taxes go hand in hand in Islamic rule. The reign of the Abū Bakr caliphate is even recorded as having fought against false prophets who disobeyed to pay zakat. ${ }^{27}$ The harmonization of the two opinions is manifested in the Zakat Law. Article 4 Paragraph (3) letters a and b, except for donations as referred to in Article 6 Paragraph (1) letter i up to letter $\mathrm{m}$ as well as zakat received by 'âmil zakat bodies or 'âmil zakat institutions established by the government or religious donations of a nature mandatory for adherents of a recognized religion in Indonesia, the provisions of which are regulated by or based on a Government Regulation can serve as a deduction for taxable assets. ${ }^{28}$

This brief clause has an important role in the development of zakat in Indonesia in the future. Zakat is a deduction for taxable assets. A policy that

\footnotetext{
${ }^{26}$ Bambang Widarno, 'Zakat Sebagai Pengurang Penghasilan Kena Pajak', Jurnal Akuntansi dan Sistem Teknologi Informasi (JASTI) 5, no. 1 (2006): 77-88.

27 Imam Taufiq, 'Transparency And Accountability In The Qur'an And Its Role In Building Good Governance', International Journal of Business, Economics and Law 6, no. 4 (2015), http://ijbel.com/wpcontent/uploads/2015/05/Law33_Imam-Taufieq_Ijbel_D33.pdf; Masyita, 'Lessons Learned of Zakah Management from Different Era and Countries', 444-46.

${ }^{28}$ Widyawati,'Filantropi Islam dan Kebijakan Negara Pasca Orde Baru: Studi Tentang UUZakat dan UU Wakaf, 88.
} 
Imam Yahya

pays attention to the existence of zakat as a developing economic system today.

Substantially, the existence of zakat in Indonesia is taken into account in the tax accounting system. So far, there has been an impression that zakat is a divine affair. At the same time, taxes are purely worldly matters, so there is no relationship between the two obligations of Muslims who happen to be Indonesian citizens. ${ }^{29}$ However, with the inclusion of zakat as a deduction from the assets subject to zakat, then in the future, zakat can become a major force for the benefit of Muslims in Indonesia.

At present, taxes are the largest income of all state financial supports. In the 2018 state budget of 1,894.7 trillion, taxes occupy the position of $85 \%$ of the total APBN (State Revenue and Expenditure Budget), namely 1,618.1 trillion. This figure is huge when compared to other revenues, such as customs, PNBP, and grants. ${ }^{30}$

According to BAZNAS records, the potential for zakat in Indonesia has not been fully exploited. This is because the implementation of zakat is mostly done independently by muzakkis. Many muzakkī are not willing to entrust their zakat to 'āmil. They still view that zakat through 'ämil only extends the zakat procedure.

If zakat can be managed professionally and transparently, the muzakki can entrust their zakat to 'āmil. Thus the potential of zakat can be utilized for problems of economic development of Muslims. Zakat is not only a religious treasure but can be useful for improving the welfare of society in general. ${ }^{31}$

However, the current condition in which zakat is counted as a tax burden is quite a matter of pride for Muslims. Why not, in a country of Indonesia which is not a religious state, the existence of zakat is included in the state financial balance. The hope is that after zakat becomes a tax deduction property, it can be used for the maximum welfare of citizens.

\footnotetext{
${ }^{29}$ Widarno, 'Zakat Sebagai Pengurang Penghasilan Kena Pajak', 81-82.

${ }^{30} \mathrm{Https}$ //www.kemenkeu.go.id/apbn2018, 'Https://Www.Kemenkeu.Go.Id/Apbn2018', 2018.

31 Masyita, 'Lessons Learned of Zakah Management from Different Era and Countries', 442; Ali Chamami Al Anshory et al., 'An Overview of Zakat Campaign in Indonesia: Case Study of BAZNAS' (Jakarta, 2020), 1, https://drive.google.com/file/d/1WIx_ARTurtioHiwx6iWvayTQklsTn2bn/view.
} 


\section{3) Oversight Function of Zakat Institutions}

As the supervisor and manager of zakat funds nationally, BAZNAS has a dual role that is not easy to implement. BAZNAS has a role in supervising LAZ and UPZ (Zakat Collecting Units) in Indonesia. LAZ and UPZ, which grow and develop in the community, must report their performance to BAZNAS at various levels of government. 32

While its role as a regulator, BAZNAS's authority has not been able to increase the confidence of the muzakki in the existence of BAZNAS. This is because BAZNAS has not fully carried out its duties as a regulator. BAZNAS, which should only play a supervisory role on zakat, also plays a role as executor (collecting, distributing and developing zakat in Indonesia). In fact, this task is evident in the Provincial BAZNAS or District/City BAZNAS. 33

According to the records of the BAZNAS Puskas, until the end of 2019, the national zakat fundraising capacity reached 6.8 trillion out of the 230 trillion potential zakats in Indonesia. ${ }^{34}$ The zakat income comes from BAZNAS at all levels and all LAZ, both national, regional and local levels. Although it is far below the potential of zakat that should be, the development of zakat in Indonesia, along with the development of Islamic economic centres in Indonesia, has developed rapidly. Various financial institutions open themselves to serve zakat collection. Even various digital company operators also offer zakat, with which, zakat is easy to pay quickly and precisely. Through go-pay, for example, and other operators, zakat, donations and alms are offered.

Article 19 of the Zakat Management Law states that LAZ is obliged to report the implementation of audited zakat collection, distribution and

\footnotetext{
32 Saidurrahman, The Politics of Zakat Management In Indonesia: The Tension Between BAZ and LAZ', 375.

33 Sheila Amalia, 'Exploring Strategies to Optimize the Collection of Zakat on Shares in Indonesia', Tazkia Islamic Finance and Business Review, 2018, https://doi.org/10.30993/tifbr.v12i2.151; Yosi Dian Endahwati, 'Akuntabilitas Pengelolaan Zakat, Infaq, dan Shadaqah (ZIS)', Jurnal Ilmiah Akuntansi dan Humaika 4, no. 1 (2014): 1356-79, https://ejournal.undiksha.acid/index.php/JJA/article/ view/4599/3527\#; Mukhibad, Fachrurrozie, and Nurkhin, 'Determinant of the Intention of Muzakki to Pay Professional Zakat'.

34 Yusuf Wibisono, 'Potensi Zakat Nasional: Peluang dan Tantangan Pengelolaan' (Depok, 8 December 2016), https://puskasbaznas.com/images/ppt/Panel-1_Yusuf-Wlbisono.pdf.
} 
utilization to BAZNAS periodically. This is intended so that zakat institutions can carry out zakat fundraising maximally. ${ }^{35}$

Based on research on the BAZNAS and LAZ contestation, it is explained that in the field there is often a contestation between BAZNAS and LAZ. Although it is recognized that the contestation is in the framework of fastabiq al-khairāt (the race for virtue), it often makes people wonder about the main duties and functions of each zakat institution.

BAZNAS's position makes the envy of other zakat institutions, especially LAZ, which has to report to BAZNAS every year. While BAZNAS, as a zakat operator, does not obstruct it. As a supervisory agency, it only fits that this position should be maximized. The potential of zakat that has not been worked on by BAZNAS is LAZ's performance which is managed professionally. Through this dual role, namely the role of zakat regulator and operator, BAZNAS is expected to be able to make zakat the economic strength of the community.

Strengthening BAZNAS not only provides a dual role but also seeks financing, both taken from BAZNAS and independent funding. The appearance of BAZNAS with state funding makes BAZNAS's strength even stronger. BAZNAS has two definite sources of funding, namely the state and a $12.5 \%$ share of 'âmil. ${ }^{36}$ The amount of state funds is adjusted to the situation in the budget conditions approved by the Council. But behind the state budget, the consistency of zakat as an Islamic philanthropic fund must be maintained. That is, zakat runs according to the rules of fiqh and is not dictated by the interests of the state.

The problem is that BAZNAS's performance is still not optimal. The development of zakat management in BAZNAS is no better than LAZ, which is purely financed only by 'āmil funds. BAZNAS moves stagnant because the management implemented is not progressive as happened in LAZ, both central and regional. LAZ's progressiveness in carrying out fundraising promotions has gained public trust, both in the aspects of fundraising and the distribution of zakat for activities that are by zakat values. Besides,

\footnotetext{
35 'UU Nomor 23 Tahun 2011 Tentang Pengelolaan Zakat' (n.d.).

${ }^{36}$ Beik, 'Fiqh Of Asnaf In The Distribution Of Zakat: Case Study Of The National Board Of Zakat Of Indonesia (Baznas)', 211-12.
} 
transparency and 'āmil accountability in carrying out their duties are one of the strong factors for the existence of the institution. In a study, it is stated that LAZ's existence so far is caused by the existence of the 'âmil accountability system for the muzakki. ${ }^{37}$

In an era of information disclosure like this, financial problems are in the public spotlight. The management of zakat assets is also in the spotlight. Muzakki's belief in zakat institutions should be balanced with the openness of 'ämil to efforts to collect and distribute zakat assets. Likewise, with 'âmil zakat as an institution, it is not only obliged to answer it to Allah, but also the muzakki. Trust in zakat institutions is an important factor to increase the role of zakat institutions in increasing muzakkī awareness.

Yosi Dian Endahwati concluded that the accountability of ZIS management at BAZ must be based on vertical and horizontal accountability. ${ }^{38}$ Vertical accountability means that the management of ZIS must adhere to the principle of the mandate, which is what is the duty of managing zakat is a mandate from Allah. Therefore, zakat managers should carry out it seriously and worship Allah.

This mandate value is then metamorphosed into spiritual accountability. This spiritual accountability describes the religious aspects that a person feels in realizing true responsibility. ${ }^{9}$ Several forms of spiritual accountability are manifested in the form of religious tourism activities in various places of worship.

Meanwhile, the second principle is horizontal accountability, namely among humans. This principle emphasizes the form of a professional and transparent attitude in the management of zakat, infaq and alms. This obligation is based on the logic that humans are given love and pleasure for the property. The joy of this should be based on God's command. It is earned

\footnotetext{
37 Imam, Institusionalisasi Zakat Pasca UU Nomor 23.2011: Kontestasi Lembaga Zakat BAZNAS dan LAZ Kota Semarang.

38 Yosi Dian Endahwati, 'Akuntabilitas Pengelolaan Zakat, Infaq, dan Shadaqah (ZIS)', 1359.

39 Mukhibad, Fachrurrozie, and Nurkhin, 'Determinant of the Intention of Muzakki to Pay Professional Zakat', 8-12.
} 
in a good way and well spent. ${ }^{40}$ The most obvious teaching is to determine a portion of the assets for zakat to be redeemed as a purifier of wealth.

For these objectives to be realized and controlled, the management of zakat is openly accountable for it. This is done so that 'âmil remains trustworthy in carrying out its main duties and functions. Borrowing Mark Turner's term in the field of budget politics, two forms of public accountability must be carried out by a company leader, including the BAZNAS and LAZ leaders, namely horizontal (community) accountability and vertical (higher authority) accountability. ${ }^{41}$

\section{Conclusion}

Based on the explanation above, some of the conclusions produced are as follows. Through Law Number 23 the Year 2011 regarding Zakat Management, BAZNAS is a non-structural institution under the President whose task is to regulate the utilization of zakat in Indonesia. The state exists to ensure the direction of state policy towards zakat management. As a major funding force in the community, BAZNAS must be able to run well and be beneficial to the community. As part of the Islamic economic system, zakat issued through the BAZNAS and/or LAZ institutions can reduce the assets subject to zakat. This is a state appreciation of the strategic value of zakat to strengthen the community's economy. The large appreciation of zakat through the Zakat Law is proven by the transparent and accountable management of zakat funds. BAZNAS, both at the central and regional levels, is assisted by UPZ and LAZ which have obtained permission from the Ministry of Religion through BAZNAS recommendations. Apart from providing recommendations, BAZNAS is also in charge of supervising the performance of UPZ and LAZ at all levels.[a]

\footnotetext{
40 Taufiq, 'Transparency And Accountability In The Qur'an And Its Role In Building Good Governance', 75-76.

41 Syahrudin Rasul, Pengintegrasian Sistem Akuntabilitas Kinerja dan Anggaran dalam PerspektifUU NO. 17/2003 tentang Keuangan Negara (Jakarta: PNRI, 2003); Elly Triantini Zusiana, 'Integrasi Hukum Pajak dan Zakat di Indonesia: Telaah Terhadap Pemikiran Masdar Farid Mas'udi', 190.
} 


\section{BIBLIOGRAPHY}

Amalia, Sheila. 'Exploring Strategies to Optimize the Collection of Zakat on Shares in Indonesia'. Tazkia Islamic Finance and Business Review, 2018. https://doi.org/10.30993/tifbr.v12i2.151.

Anshory, Ali Chamami Al, Muhammad Indra Saputra, Siti Maulida Adhiningsih, and Muhammad Hasbi Zaenal. 'An Overview of Zakat Campaign in Indonesia: Case Study of BAZNAS'. Jakarta, 2020. https://drive. google.com/file/d/1WIx_ARTurtioHiwx6iWvayTQklsTn2bn/view.

Arskal Salim. The Shift in Zakat Practice in Indonesia: From Piety to an Islamic Socio-Political-Economic System. Chiang Mai: Silkworm Books, 2008.

Beik, Irfan Syauqi. 'Fiqh Of Asnaf In The Distribution OfZakat: Case Study Of The National Board Of Zakat Of Indonesia (Baznas)'. AL-INFAQ: Jurnal Ekonomi Islam 6 (2015): 201-16.

Canggih, Clarashinta. 'Potensi dan Realisasi Dana Zakat Indonesia',. Al-Uqud: Journal of Islamic Economics 1 (2017): 2548-3544.

Dahlan, Moh. 'Hubungan Agama dan Negara Di Indonesia, ANALISIS:Volume 14, Nomor 1, Juni 2014.' ANALISIS: Jurnal Studi Keislaman 1 (2014).

Doktoralina, Caturida Meiwanto. 'Mobilisation of Income Zakat Payment In Indonesia'. IKONOMIKA: Jurnal Ekonomi dan Bisnis Islam 3, No. 2 (2018): 189-204.

Effendy, Bahtiar. Islam dan Negara: Transformasi Pemikiran dan Praktek Politik Islam di Indonesia. Jakarta: Paramadina, 1998.

Elly Triantini Zusiana. 'Integrasi Hukum Pajak dan Zakat di Indonesia: Telaah Terhadap Pemikiran Masdar Farid Mas'udi'. Al-Ahkam: Jurnal Pemikiran Hukum Islam 23, No. 2 (2013).

Esawe, Ahmed, Karimt Esawe, and Narges Esawe. 'Using Zakat to Build the Resilience of Communities to Disasters: Evidence from Egypt'. SSRN Electronic Journal, 2019. https://doi.org/10.2139/ssrn.3331506.

Ghofur, Abdul. 'Pergulatan Hukum dan Politik dalam Legislasi UU No. 21 Tahun 2008 Tentang Perbankan Syari'ah'. Al-Ahkam, 2013. https://doi.org/ 10.21580/ahkam.2013.23.1.73.

Hasan, Hamsah. 'Hubungan Islam dan Negara: Merespons Wacana Politik Islam Kontemporer di Indonesia'. Al-Ahkam, 2015. https://doi.org/10.21580/ ahkam.2015.1.25.192.

Heywood, Andrew. Political Theory An Introduction. New York: PALGRAVE MACMILLAN Houndmills, 2004. 
Imam Yahya

Https://www.kemenkeu.go.id/apbn2018. 'Https://Www.Kemenkeu.Go.Id/ Apbn2018', 2018.

Imam, Yahya. Institusionalisasi Zakat Pasca UU Nomor 23.2011: Kontestasi Lembaga Zakat BAZNAS Dan LAZ Kota Semarang. Semarang: LP2M UIN Walisongo, 2015.

Iswari, Putu Widhi, and Maskur Rosyid. 'Tinjauan Prinsip Good Governance dan Perpektif Islam dalam Operasional Lembaga ZIS'. Jurnal Manajemen Zakat dan Wakaf 1, no. 1 (12 April 2020): 88-105. http://ejournal. iainsurakarta.ac.id/index.php/filantropi/article/view/2367.

Junaidi, Abdullah. 'Institusi Pengelola Zakat dalam Hukum Positif di Indonesia'. ZISWAF 5, no. 1 (2018): 171-85.

Lisa, Oyong. 'Implementation of Management Zakat as a Local Revenue'. Journal of Asian Scientific Research 5, no. 8 (2015): 418-30. https://doi.org/ 10.18488/journal.2/2015.5.8/2.8.418.430.

Masyita, Dian. 'Lessons Learned of Zakah Management from Different Era and Countries'. Al-Iqtishad: Jurnal Ilmu Ekonomi Syariah Oournal of Islamic Economics) 10, no. 2 (2018).

Al-Mawardī, Abū al-Ḥasan. Al-Aḥkām Al-Sulțāniyah. Beirut: Dār al-Fikr, n.d.

MD, Moh Mahfud. Membangun Politik Hukum, Menegakkan Konstitus. Jakarta: LP3ES, 2006.

_—_. Politik Hukum di Indonesia. Jakarta: LP3ES, 1998.

Monzer Kahf. 'Zakat: Unresolved Issues in the Contemporary Fiqh'. Journal of Islamic Economics, 1989.

Mubarok, Jaih. Fiqh Siyasah. Bandung: Pustaka Bani Quraisy, 2005.

Mukhibad, Hasan, Fachrurrozie Fachrurrozie, and Ahmad Nurkhin. 'Determinant of the Intention of Muzakki to Pay Professional Zakat'. Share: Jurnal Ekonomi dan Keuangan Islam, 2019. https://doi.org/ 10.22373/share.v8i1.4573.

Rasul, Syahrudin. Pengintegrasian Sistem Akuntabilitas Kinerja dan Anggaran dalam Perspektif UU NO. 17/2003 tentang Keuangan Negara. Jakarta: PNRI, 2003.

Saidurrahman. 'The Politics of Zakat Management In Indonesia: The Tension Between BAZ and LAZ'. Journal of Indonesian Islam 7, no. 2 (2013).

Shaharuddin, Syarul Azman, Muhammad Yusuf Marlon, Mariam Abd Majid, Abur Hamdi Usman, Fakhri Sungit, and Zulkifli Abd Hamid. "The Relationship between Impact of Zakat Distribution and Religious Practice 
among Muallaf in Selangor'. Humanities and Social Sciences Reviews, 2019. https://doi.org/10.18510/hssr.2019.7448.

Suny, Ismail. 'Tradisi dan Inovasi Keislaman di Indonesia dalam Bidang Hukum Islam'. In Hukum Islam dalam Tatanan Masyarakat Indonesia, edited by Cik Hasan Bisri. Jakarta: Logos Publishing House, 1998.

Supena, Ilyas, and Darmuin. Manajemen Zakat. Semarang: Walisongo Press, 2009.

Syaifuddin, Tsalis. 'Implementation of Data Envelopment Analysis (DEA) in Measuring the Efficiency Zakat Fund Management'. Indonesian Journal of Islamic Economics Research, 2019. https://doi.org/10.18326/ijier.v1i1. 2872.

Taufiq, Imam. 'Transparency And Accountability In The Qur'an And Its Role In Building Good Governance'. International Journal of Business, Economics and Law 6, no. 4 (2015). http://ijbel.com/wp-content/uploads/2015/05 /Law33_Imam-Taufieq_Ijbel_D33.pdf.

Triningsih, Anna. 'Politik Hukum Pengujian Peraturan Perundang-Undangan dalam Penyelenggaraan Negara'. Jurnal Konstitusi 13, no. 1 (20 May 2016): 124. https://doi.org/10.31078/jk1316.

Wibisono, Yusuf. 'Potensi Zakat Nasional: Peluang dan Tantangan Pengelolaan'. Depok, 8 December 2016. https://puskasbaznas.com/images/ppt/ Panel-1_Yusuf-WIbisono.pdf.

Widarno, Bambang. 'Zakat Sebagai Pengurang Penghasilan Kena Pajak'. Jurnal Akuntansi dan Sistem Teknologi Informasi (JASTI) 5, no. 1 (2006): 77-88.

Widyawati. 'Filantropi Islam dan Kebijakan Negara Pasca Orde Baru: Studi tentang UU Zakat dan UU Wakaf. UIN Syarif Hidayatullah, 2011.

Yosi Dian Endahwati. 'Akuntabilitas Pengelolaan Zakat, Infaq, dan Shadaqah (ZIS)'. Jurnal Ilmiah Akuntansi dan Humaika 4, no. 1 (2014): 1356-79. https://ejournal.undiksha.ac.id/index.php/JJA/article/view/4599/352 7\#. 
